\title{
ROLES OF FACULTY IN TEACHING ASYNCHRONOUS UNDERGRADUATE COURSES
}

Libby V. Morris, PhD

Associate Professor

Institute of Higher Education

University of Georgia

Haixia $X u$

Institute of Higher Education

University of Georgia

Catherine L. Finnegan, EdD

Associate Director

Assessment and Public Information

Advanced Learning Technologies

Board of Regents of the University System of Georgia

\begin{abstract}
Although the availability of web-based education and the number of totally asynchronous courses have grown exponentially in the last decade, the literature on online instruction offers limited empirical guidance to faculty teaching in this environment. Much of the literature is anecdotal and prescriptive, and much more research needs to be done to situate research in practice settings. This study examines faculty roles in the online environment through the perceptions of faculty teaching online and through the archival analysis of their courses. Data were collected through document analysis of ten online courses and from interviews with thirteen instructors in the humanities and social sciences. Using Berge's typology of online facilitator roles, this study examined the relationship between roles as perceived and enacted by faculty, identified wide variations in faculty roles and participation between experienced and novice instructors, and explored the relationship between faculty workload and perception of facilitation in the online environment. Directions for future research are suggested.
\end{abstract}

\section{KEYWORDS}

online teaching, faculty role, instructional workload

\section{INTRODUCTION}

Web-based learning is growing exponentially in higher education. According to a report by the Sloan Consortium [1], 81 percent of all institutions of higher education offered at least one fully online or blended course in 2002, enrolling over 1.6 million students. The number of students taking online courses was projected to increase by about 20 percent in the academic year 2002-3. Considering the increasing enrollments in online courses and the resulting shift in the nature of student-teacher interaction, it is important to study the teaching and learning relationship in the asynchronous online environment. 
Specifically, it is important to know more about the actual roles and instructional practices of faculty online so that research-based practices can be recommended for faculty teaching online.

To address these issues, we designed a study that was guided by three research questions:

1. How do instructors perceive their roles in the online environment?

2. What roles do instructors enact in the online environment?

3. What is the relationship between faculty workload and faculty roles?

Answers to these questions will contribute to the literature of online education and could be used to design professional development opportunities for faculty members who will teach online courses in the future. Data were collected through (a) semi-structured interviews with thirteen faculty members who taught totally asynchronous online courses in Fall 2003 or Spring 2004 and (b) document analysis of ten archived online courses. The research questions were influenced by the literature on teaching online, specifically Berge's typology on the roles of online instructors [2].

\section{REVIEW OF THE LITERATURE}

In the last decade, the literature on online education has grown rapidly. In contrast to earlier literature that was primarily prescriptive or anecdotal, more research-based studies have emerged. The literature that is relevant to this research includes studies of the roles of online faculty, online facilitation, and faculty workload in the virtual environment.

Palloff and Pratt in an empirical study [3] asserted that as a result of the lack of face-to-face contact and the largely asynchronous nature of this environment, online instructors experience educational challenges as well as "a new set of physical, emotional, and psychological issues" (p.7). Not the least of these challenges is the role of the faculty member in the online environment. In an earlier and oft-cited work, Berge [2] proposed that the most important role of the online instructor is to accept responsibility for keeping discussions on track, to contribute special knowledge and insights, to weave together various discussion threads and course components, and to maintain group harmony. Acknowledging that there are many necessary conditions for successful online teaching, he proposed four categories of responsibility: pedagogical (i.e., intellectual tasks), social (i.e., community-building), managerial (i.e., organizational, procedural, and administrative), and technological functions. Allen [4], in teaching calculus online, felt that there was a loss in the absence of face-to-face contact and in-class demonstrations and thereby reported challenges such as giving proper and timely mathematical help, and addressing student isolation and frustration due to lack of face-to-face meetings.

In a recent study of the roles of the online instructor, Collis and Nijhuis [5] focused on the management tasks of online faculty, which they defined as all tasks outside of content-specific work. Ko and Rossen [6] also examined management issues and suggested paying particular attention to (a) record keeping and file management, (b) managing online communications, (c) encouraging participation and managing workload, (d) team teaching online, and (e) managing online student behavior. Bibeau [7] explored the role of social presence and its relation to feelings of isolation and connectedness in the online environment and concluded that specific strategies are needed to build a community of learners. Bonk and Dennen [8] lamented the dearth of knowledge about pedagogical tools and strategies for the web, and they described a number of pedagogical practices, including a summary of the pedagogical, social, managerial, and technological strategies in online instruction. 
Many authors define the primary faculty role online as one of facilitator or moderator, and many publications deal with how to be an effective facilitator or moderator. For example, Bischoff [9] argued that the key to effectiveness in the online environment is the instructor's ability to assume the role of facilitator. Specifically, an instructor's performance is closely related to his or her ability to maintain visibility, give regular feedback, provide high-quality materials, and remove obstacles to student retention. Easton's research [10] confirmed that in addition to many skills similar to those of face-to-face teaching, online instructors take on new roles, such as instructional designer and interaction facilitator. Heerema and Rogers [11] compared online education to correspondence courses, and they emphasized the instructor's role as mediator of content in the online course. Addesso [12] stressed how online facilitation is similar to traditional facilitation, and he described a model of online facilitation including how to (a) break the ice in a positive way, (b) use specific facilitation skills, and (c) deal with common problems. Collison [13] explored in depth the role of instructors in the virtual classroom, and he proposed three principles for effective moderating: (a) moderating takes place in both a professional and social context, (b) the style of "guide on the side" (vs. "sage on the stage") is most appropriate for leading a virtual learning community, and (c) online moderation is a craft that has general principles and strategies that can be learned over time.

Although much of the literature suggests that the primary pedagogical role of the instructor is that of discussion facilitator or moderator, the research literature on online discussion is still in its infancy, and much of the work is prescriptive. For example, Hiss [14] discussed how online facilitators should "talk" to their students using humor, special languages, and other forms of online communication to humanize the online environment. Berge and Muilenburg [15] explored the design of effective questions for online discussion and identified the right questions as those that foster learner engagement in the learning process. Similarly, Clark [16] focused on the methods to stimulate discussion and collaboration in the online environment and identified methods to facilitate online discussion. Astleitner [17] proposed that online discussion places an emphasis on students' comprehension and knowledge of argumentation and thus on how to interact with content and each other in a meaningful way, and he acknowledged that students may not be equipped with such skills and that faculty may not have sufficient skills in monitoring discussions or creating productive communities of online learners.

The research literature also acknowledges a steep learning curve for novice instructors. In one of the major books on online teaching, Palloff and Pratt [18] recognized the difficulty in transitioning to the online environment and in working with courses developed by others. In a qualitative study, Conrad [19] interviewed novice online instructors in a graduate program and found that "their overall concerns were content-oriented” (p. 42). Although all considered themselves content deliverers, these first-time online instructors revealed little awareness of such issues as collaborative learning, learner's social presence, or the role of community building in the online learning environment. Kanuka et al. [20] extended the understanding of the impacts on instruction when asynchronous text-based Internet communication technology is integrated into distance courses. Interviews with 12 university instructors revealed that emotional distance, feedback, and structure were concerns expressed by distance education instructors; however, as instructors in distance programs gained experience, they are more adept at translating face-toface institutional strategies to the online classroom, and they learned the technical aspects necessary for effectiveness with these communication tools.

The integration of technology into instructional processes also poses various challenges to online instructors. One of the primary challenges reported by online instructors is the increased workload involved in online teaching. Two national reports by the National Education Association [21] and the National Center for Educational Statistics [22] indicated that online instructors spent much more time on preparation than their colleagues in the traditional classroom, a finding that has been consistently reported 
elsewhere [23, 24, 25, 3, 5]. As a result, the expectation of an increased workload has inhibited some faculty members from teaching online [26, 27, 28, 29, 5].

The majority of studies addressing faculty time and workload have relied on survey and faculty perceptions; few studies have explored the issue of workload and time commitment systematically and contemporaneously. Notable are the studies that follow. Visser's research [30] revealed that the overall time for developing, delivering, and assessing courses delivered in a combination of internet-based instruction and two-way interactive television was more than twice that for traditional courses. DiBiase [31], however, presented data collected in a year-long study in which he and his assistants kept detailed records of the time spent in teaching and maintaining two comparable university courses, one face-to-face and the other distance. He found that, in his case, distance courses took less time to prepare for; distance education courses required 2.7 hours for each student as compared to 3.2 hours for each student in faceto-face courses. Moore [32] compared the seemingly contradictory findings from Visser's study and DiBiase's research and concluded that these contradictions may be attributed to the fundamental differences between the courses in each study in terms of the subject matter, the level of students' previous education, the nature and extent of institutional support, and even the mixture of technologies. Another time-on-task analysis by DiBiase [33] explored the relationship between enrollment and instructor workload in the asynchronous online courses, and the research confirmed the strong curvednot linear-relationship between these two variables.

Several authors have attempted to explain an increased workload by citing pedagogical and technical challenges in the online environment. Wilson [34] concluded that it takes more time to develop online courses, to interact with students, and to grade students' assignments electronically, all of which account for the increased workload in the online environment. In addition, her study found that workload is affected by student familiarity with computer and equipment problems: when students have insufficient technological skills, instructors must spend additional time helping students with technical problems. Lazarus [35], using a longitudinal case study design, examined three courses and found that participation in and grading of the discussions took the greatest amount of time and that this factor remained steady across the semester.

In summary, this review shows that a substantial body of literature seeks to identify and describe faculty roles online and to advance instructional strategies believed to be effective in the online environment. The literature also reveals that faculty perceive teaching online to be more time-consuming than face-to-face teaching, yet documented time and tasks studies yield mixed findings regarding the faculty workload in this environment. To date it is not clear what accounts for these differences and, specifically, what teaching practices are likely to make the faculty workload manageable. Clearly there remains a need for empirical studies that characterize real, situated faculty practice. Such studies will inform critical readings of prescriptive studies and provide an empirical basis for the design of professional development programs.

\section{RESEARCH DESIGN}

The purpose of this study was to explore the roles that faculty enact in the online environment through a series of semi-structured interviews and analysis of online instruction. The primary research questions were as follows:

1. How do instructors perceive their roles in the online environment?

2. What roles do instructors enact in the online environment?

3. What is the relationship between faculty workload and faculty role? 
The setting for the study was the electronic core curriculum, eCore ${ }^{\circledR}$, developed and coordinated by Advanced Learning Technologies, a division within the University System of Georgia's Office of Academics and Fiscal Affairs. The curriculum consists of lower-division, general education courses, and students across the system are eligible to enroll in one or more of these each term. A unique aspect of the research setting is that the courses are developed by teams of faculty together with instructional and web design experts using a consistent template and design standards for online courses. As a result of the collaborative development effort, these courses are not only rich in content but also highly structured, with detailed instructional activities and processes. For example, each course contains an online "lecture," questions for guided reading, self-tests, discussion questions, interactive activities, and assessment activities. Guidelines for student participation are included. Following course development, the online courses are taught asynchronously and entirely online by faculty from various institutions in the system.

\section{A. Study Sample}

Twenty-two instructors who taught online in Fall 2003 or Spring 2004 were contacted, and a total of thirteen agreed to participate in this study. These instructors represent eleven institutions and seven disciplines in humanities and social sciences. Ten of the thirteen instructors had taught online three or more terms, and the remaining three were in their second online course at the time of interviews. Class sizes averaged around twenty students. Prior to teaching these courses, faculty members are encouraged to participate in a short-term online course developed for potential instructors by the professional staff. Technology issues in this study are managed by technical support provided by an office of the system; consequently, instructors may focus on instructional strategies while receiving support for other courserelated problems.

\section{B. Data Collection and Analyses}

This study relied on two primary data sources: semi-structured interviews with faculty teaching online and an analysis of archived online courses taught by those interviewed. A total of thirteen interviews were conducted with online instructors during Fall 2003 and Spring 2004. Seven were conducted face-to-face, and the remaining six were by telephone. We used a semi-structured protocol to guide the interviews. Each interview lasted approximately forty-five minutes to one hour and was audio-taped and transcribed to verify accuracy in the note-taking process. Each interview asked about the faculty member's role in the online environment, how the role was enacted, and to a lesser degree the perception of the online workload. The interviews were analyzed using inductive analysis [36, 37], following the coding process defined by Charmaz [38].

At the end of each interview, we requested and received permission from those interviewed to have access to a previously taught course. We intentionally chose to analyze archived courses so that as observers we would not affect either faculty or student performance in the online course. Due to technological difficulties, we only had access to ten online courses. Reviewed were the course syllabus, student guide, and discussion board. The literature indicates that discussion is a primary instructional method for online courses; therefore, we used the discussion board as the primary vehicle to view the instructors' online roles and activities. Due to issues of confidentiality, the research did not include access to personal e-mails within the WebCT environment.

To analyze the archived courses, the syllabus and student guide were read to gain an understanding of the overall structure and requirements of the course; then, all of the discussion postings were compiled, read, numbered, and classified. In the course of data analyses, Berge's research on the role of online instructors [2] became a useful framework in the analysis of the interviews and the review of the archived courses. 
Acknowledging that there are many necessary conditions for successful online teaching, Berge asserted that an online instructor enacts four roles to model effective online teaching, respectively, pedagogical, social, managerial, and technological. Table 1 summarizes Berge's definitions of the four roles and the researchers' examples of associated tasks.

Table 1: Typology of the Roles of Online Instructors

\begin{tabular}{|l|l|l|}
\hline Online Role & Definition & Tasks \\
\hline Pedagogical & $\begin{array}{l}\text { "Revolving around duties as an educational } \\
\text { facilitator; using questions and probes for } \\
\text { student responses that focus discussions on } \\
\text { critical concepts, principles and skills" }\end{array}$ & $\begin{array}{l}\text { Provide guidelines for assignments, } \\
\text { offer intellectual feedback, explain } \\
\text { issues, direct comments toward the } \\
\text { content and learning objectives, } \\
\text { evaluate student projects and } \\
\text { contributions, etc. }\end{array}$ \\
\hline Social & $\begin{array}{l}\text { "Promoting human relationships, developing } \\
\text { group cohesiveness, maintaining the group as a } \\
\text { unit, and in other ways helping members to work } \\
\text { together in a mutual cause" }\end{array}$ & $\begin{array}{l}\text { Support the development of } \\
\text { collaborative learning and a social } \\
\text { community. } \\
\text { Express support for the learning } \\
\text { process and individual needs. }\end{array}$ \\
\hline Managerial & $\begin{array}{l}\text { "Organizational, procedural, administrative } \\
\text { tasks; involving setting the agenda for the } \\
\text { conference: the objectives of the discussion, the } \\
\text { timetable, procedural rules and decision-making } \\
\text { norms" }\end{array}$ & $\begin{array}{l}\text { Set up discussion forum, release } \\
\text { discussion questions, answer } \\
\text { administrative questions. }\end{array}$ \\
\hline Technical* & \begin{tabular}{l} 
"Make the technology transparent” \\
\hline
\end{tabular} & $\begin{array}{l}\text { Provide students with, or direct } \\
\text { students to, technological } \\
\text { assistance. }\end{array}$ \\
\hline
\end{tabular}

*Because system support staff assisted students and faculty with technology issues, this role was not included in the analyses.

Issues of validity were addressed through collecting data by multiple researchers from multiple sources (i.e., interviews and document analysis) and by quoting the research participants' own account of their teaching. By using researcher and method triangulation and thick description [39, 40], data collection and analysis in this study conform to accepted standards for qualitative research [41, 42].

\section{RESEARCH FINDINGS}

Data from the interviews and document analysis were combined to describe how the instructors perceived their roles in the virtual classroom (interview data), how they carried out and prioritized their roles (archival analysis), and how they perceived and handled the workload issue (interview and archival data).

\section{A. Perceived Roles of Online Instructors}

Interviews with the thirteen online instructors revealed that they perceived three primary roles in the online environment: course customization, course facilitation, and grading and assessment. 


\section{Course Customization: Managerial/Pedagogical Role}

All except two of the instructors reported customizing the "canned" course in the form of checking and updating links, testing and fixing quiz errors, adding or deleting content, revising discussion questions, revising instructional activities, or structuring the discussion forums. For example, some instructors reported tailoring the discussion questions to reflect areas of expertise, or editing the unit question to make the discussions more engaging. Some instructors added relevant materials when they disagreed with the developed materials. In some cases, instructors made decisions about adopting or ignoring certain instructional activities, such as a group project, based on their teaching experience. Generally speaking, experienced instructors were more likely to customize their courses prior to the semester; some considered such advance planning a time-saver in the long run. One instructor explained by saying,

"[I] set up the calendar, the syllabus, set up the discussion but keep them closed until I'm ready to open them. [I] set up the quizzes; same thing-keep them locked until I'm ready. Prepare the initial postings, and somewhere in the future you can pick a date and release them on. So it is nice. I can set it up and know the software will automatically do it for me. So I try as much as possible to get those things done. That helps. And then I can sit up and relax and answer posts, instead of having to worry about the set-up ... It (planning the course) is a big advantage and a big time-saver, if we have time before the beginning of the semester to get the course and get it set up. So that saves a lot of time."

The activities mentioned in the quotation above are clearly managerial ones, but other pre-course activities, e.g., deciding on the content to include or drop, could be considered a pedagogical decision. According to those interviewed, the primary effort prior to the beginning of the course was setting up the calendar and doing other primarily management activities so that the course would run smoothly once the term began.

\section{Course Monitor/Facilitator: Pedagogical/Social/Managerial Role}

Half of the interviewed instructors implied or stated explicitly that students should take the primary responsibility for learning, and that the role of the instructor is to facilitate the learning process. For example, one instructor who had taught online course for three years stated,

"I always see my roles as a facilitator of learning. I don't know what people define teaching to be, but what I want to try to do is to create an opportunity for the students to learn information and try to facilitate the process while they are doing that. I think adults, including eighteen-, nineteen-year-olds, should be responsible for themselves and for their activities. So I don't think it is appropriate for me to take the responsibility for making them learn. But I do want to create an opportunity and do everything I can to support that as they do throughout the process."

A novice instructor who was teaching his second online course described his role in the online class in a similar way,

"They (online students) are forced to learn the content really on their own. They have to put the content time on their own. I mean, I answer their questions constantly for them, but in term of real content instruction, they have to absorb the content on their own. The only thing I really did is to clarify and give broader discussion ... opportunities and my role on this is largely as instructor, structuring the interaction, evaluating their work and giving them feedback on that.” 
Another experienced instructor described her role as "guide on the side, not sage on the stage," saying, "That is what we are really trying to mentor all the faculty to do. But I try to, for example, get them (online students) started in our discussion forum, and I back off, and let them run with it. And most of the time it works very well. I try to make a point of, even if just saying "nice post," "good comments," I try to always respond to students" posts, sometimes it takes a lot of time, especially early in a semester. As the semester goes on, I tend to do less and less of that, and let them take the responsibility of their learning and for managing the discussion board on their own. And I think that is good, because they kind of like (that), need a little bit hand-holding at the beginning of a semester, but by the end most of them are just very competent and almost running the course by themselves."

In contrast, a senior professor, experienced in both traditional and online education, simply characterized his role as "teacher." He reported responding to every single student posting, and he took pleasure in doing this. As a group, the instructors reported during the interviews that they were involved in the online discussions, although in varying degrees, and they believed they were "present" in the online environment.

\section{Evaluator/Grader: Pedagogical Role}

A review of the course syllabi revealed that the online courses are intensive with readings, discussions, writing assignments, and proctored exams. The instructors confirmed this observation. As a result of the frequency and scope of student work, all the instructors reported spending a disproportionate amount of time on grading assignments and providing evaluation feedback. A few of them reported grading student discussions on a weekly basis and providing individual students with a status report on performance somewhere in the middle of the semester, and most of those interviewed reported providing detailed comments on students' writing assignments within WebCT.

Due to time constraints, some instructors in this study reported prioritizing grading of written assignments and managerial tasks over participating in the discussions. According to an instructor who was teaching his second online course:

"I don't feel like I'm doing a lot of teaching here (online). I feel I am doing a lot of grading and structuring, but I actually wish I was really doing some teaching, and we were interacting back and forth... But the more demanding, pressing issue is to get grades back, get lessons open, and make sure the students have access to the course. And so you spend a lot of time doing that kind of stuff, and less of the stuff, which I kind of like, which is the interaction with students and really that sort of thing."

During the interviews, the instructors could describe in great detail their process for grading exams or other students' work. The pedagogical role in evaluation was clearly articulated; less well described was the pedagogical role in specifically online activities, such as facilitating learning or leading discussions.

In general, the interviews suggested that most online instructors attached much importance to the managerial and pedagogical tasks prior to course delivery, and that most tended to prioritize managerial over pedagogical roles during course delivery. Most of the online instructors felt the pressure to prioritize grading over participating in the discussion forum as the former was considered more urgent than the latter, although they were aware of the importance of facilitating student discussions. 


\section{B. Observed and Enacted Roles of Online Instructors}

Access to the ten archived courses allowed the researchers to look in depth into how the online instructors enacted their instructional roles online and to compare faculty perceptions and enactments of online roles. The archival analysis provided insight into the difficulty some faculty experienced in describing their online instructional activities—specifically, facilitation.

Below are examples of faculty postings at the discussion board classified according to Berge's three roles (i.e., pedagogical, social, and managerial). Following the examples are figures and tables classifying and comparing the roles of novice and experienced faculty.

\section{Examples of Instructor Postings at the Discussion Board}

- Group feedback: "Students: You did a fine job role playing, except that most of you were too nice to the Indians. Had the colonists been so good to the Indians ... Remember, history is not made up of 'might have been,' but what actually took place.” (Pedagogical)

- Group feedback: "I just want to commend everyone for doing such a good job with this discussion/debate. Many of you have done well in defending your positions, and you are engaged in good debate with other students while being very civil and polite. Anyway, good job, folks, and keep up the good work! Unit 5 will be open 'til early Monday for those who haven't had a chance to debate." (Pedagogical)

- Individual feedback (disagreement): "I really like your descriptions of the Tao and how it works in the ideal, but don't be surprised if the Legalists and Confucians try to dismantle your argument.” (Pedagogical)

- Individual feedback (probing): "One quick question: if history is a science, what IS history? Want to stab at defining it?" (Pedagogical)To individuals: "Welcome, (student name)! Wow, you've got a lot on your plate; I wish you success in all your goals.” (Social)

- To class: "Welcome to the Photo Gallery! Please feel free to post photos of yourself or your family if you wish!" (Social)

- Discussion questions and requirements: "Unit 5, China, has a very interesting discussion assignment. You initial post is due to this discussion area by (date). After you make your initial posting, you should respond to arguments contained in at least two other postings from different characters' points of view. The postings should be at least one paragraph in length. Use available evidence to refute that character's position and further support your own.” (Managerial)

- Proctored exam: "Mm, not sure ... Can you give (an administrator's name) a call to see if she has an alternative site there [for your proctored exam]? Do you have her phone number?" (Managerial)

- Discussion forum: "The technical assistance board is designed ESPECIALLY as a place to come and get technical questions answered. Not sure about something in WebCT or on a computer? Maybe someone can help. Post your tech questions and get answers. Don't forget to use the Help tool, too.” (Managerial)

Clearly, classifying the instructor discussion postings according to the type of roles enacted was timeconsuming and difficult, and, as can be seen above, some messages had multiple dimensions. For example, on the second posting above, the researchers deliberated as to the primary intention of the posting. The post was labeled "pedagogical" primarily because the instructor was speaking directly to group performance on a specific instructional activity. Posts that were classified as "social" in nature were more generic and were not directed specifically to learning outcomes or performance. Through multiple reviews, we felt confident that the posts were classified sufficiently to indicate the prevalence of the social, managerial, and pedagogical roles enacted at the discussion board. 
After each post was coded, the posts were aggregated by category to indicate the prevalence of each, by course, for faculty experience, and vis-à-vis student postings. As the tables and figures below reveal, the degree of faculty involvement, as defined by participation in the discussions, varied considerably by course.

Figure 1 shows a wide range of discussion postings by course, by students, and by instructors, even though the class size was similar across the ten courses. For example, the total postings across the ten courses ranged from approximately 500 to almost 2,000, student postings varied from 451 to nearly 1,900 , and the instructor postings ranged from 5 to nearly 500. Discussions in each course counted for approximately 20 percent of the grade, which motivated the students to create original and follow-up posts; consequently, it is not surprising that student postings account for the great majority of posts in all of the ten courses.

Figure 1: Discussion Postings by Students and Instructors

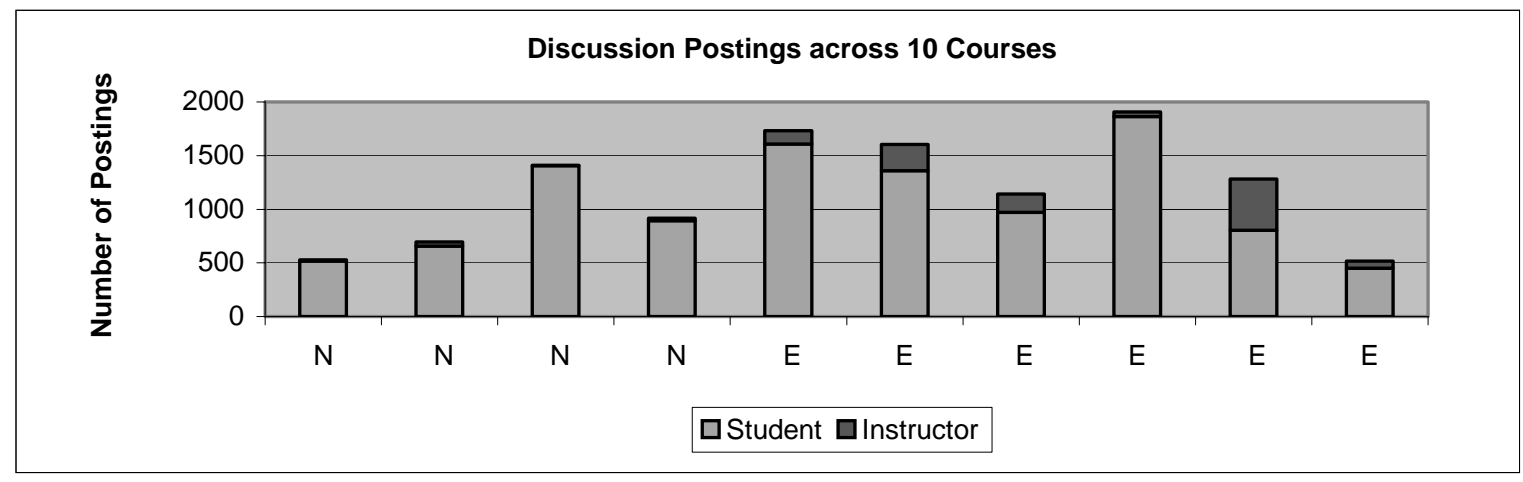

$\mathrm{N}=$ Novice E=Experienced (The bars are ordered from least experienced to most experienced.)

Figure 1 illustrates the wide variation in faculty presence in the discussion board of the observed online courses. For example, one instructor posted more than one-third of all class postings, whereas the other instructors entered into the discussions much less frequently, and some even posted minimally. When examined by faculty experience in the online environment, the courses taught by the novice instructors (i.e., three or fewer semesters) had fewer postings overall than those taught by their more experienced counterparts. The novice instructors had an average of 19 instructor postings and 869 student postings per course, whereas in comparison the courses by the more experienced instructors had an average of 193 instructor postings and 1,176 student postings. A wide range of instructor participation also existed within the experienced group, with instructor postings ranging from 42 to 480 .

As described above, the discussion posts by the instructors were categorized according to the primary role represented in the posting. Figure 2 shows that among the ten online instructors, only four enacted the pedagogical roles as the leading role; the four were classified as experienced online instructors. Only two instructors showed a roughly equal balance between pedagogical, social, and managerial postings; one of these, however, posted a low number overall. Interestingly, only one of the experienced instructors posted fewer than fifty posts overall, the level below which all of the novices fell. 
Figure 2: Enactment of Berge's Three Faculty Roles by Instructor

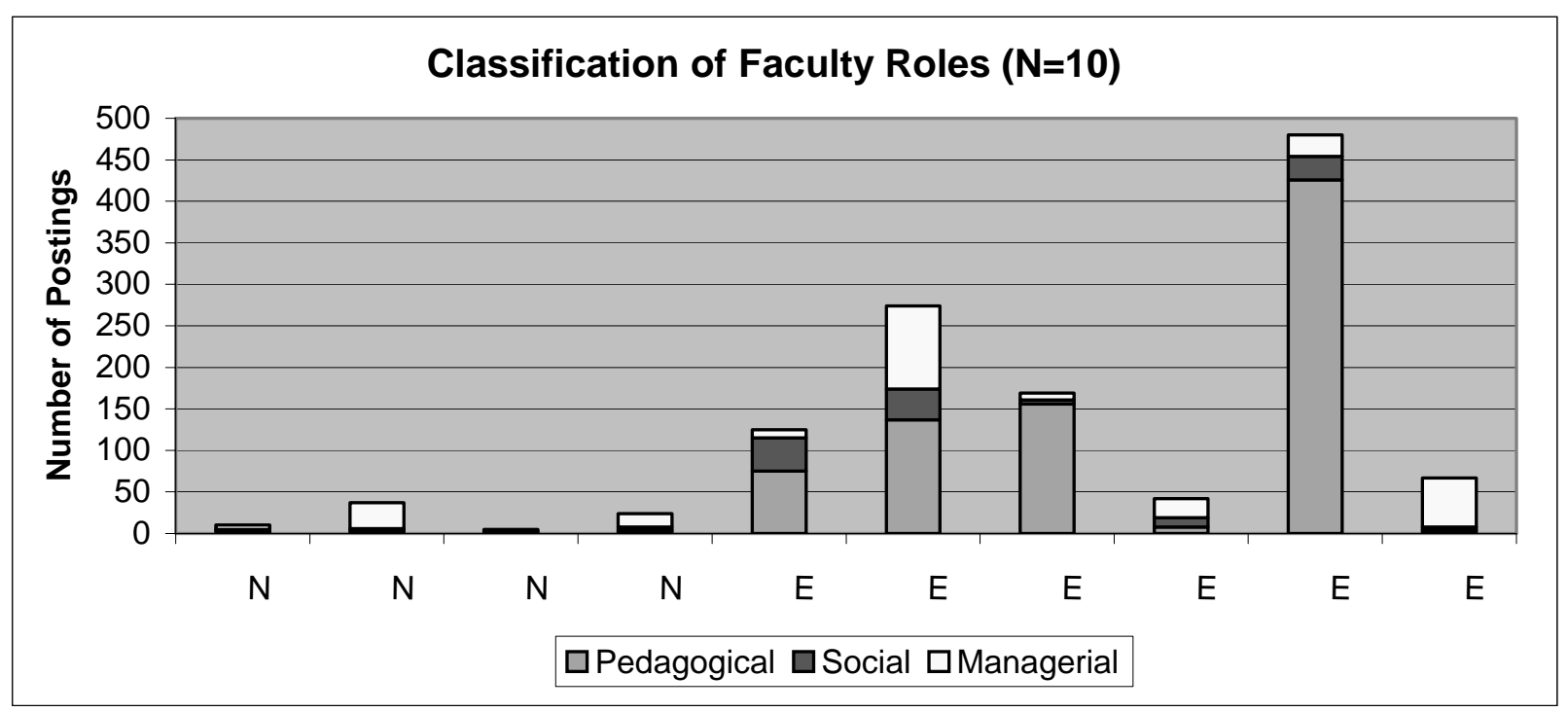

Interestingly, none of the novice instructors enacted the pedagogical role as the primary role. Table 2 shows the number of postings classified by novice and expert instructors. The data show that more experienced online instructors tended to focus on intellectual tasks, whereas their novice counterparts seemed to spend most of their time on managerial tasks. Both groups spent less time enacting the social role.

Table 2: Comparison of Novice and Experienced Online Instructors

\begin{tabular}{|c|c|c|c|c|c|c|c|}
\hline Category & & $\begin{array}{c}\text { Student } \\
\text { Postings }\end{array}$ & $\begin{array}{c}\text { Instructor } \\
\text { Postings }\end{array}$ & Pedagogical & Social & Managerial & $\begin{array}{c}\text { Ratio of Instructor- } \\
\text { Student Postings }\end{array}$ \\
\hline \multirow{2}{*}{$\begin{array}{c}\text { Novice } \\
(\mathrm{N}=4)\end{array}$} & Total & 3473 & 76 & 13 & 9 & 54 & N/A \\
\cline { 2 - 8 } & Average & 869 & 19 & 3 & 2 & 14 & $46: 1$ \\
\hline \multirow{2}{*}{$\begin{array}{c}\text { Experienced } \\
(\mathrm{N}=6)\end{array}$} & Total & 7054 & 1157 & 806 & 125 & 226 & N/A \\
\cline { 2 - 8 } & Average & 1176 & 193 & 134 & 21 & 38 & $6: 1$ \\
\hline \multirow{2}{*}{$\begin{array}{c}\text { Overall } \\
(\mathrm{N}=10)\end{array}$} & Total & 10528 & 1233 & 819 & 134 & 280 & N/A \\
\cline { 2 - 8 } & Average & 1053 & 123 & 82 & 13 & 28 & $8.5: 1$ \\
\hline
\end{tabular}

\section{Perception of Workload}

Surprisingly, only four of the thirteen instructors reported a greatly increased workload in teaching online as compared to face-to-face courses; this finding contradicts most of the literature and our previous research. One experienced online instructor stated it this way:

"I think I’ve got a little more efficient in some of the areas. I can go back and use posts I used previously. Now I know pretty much what the problems will be, so I can pretty much anticipate before they happen ... [For example,] from the previous semesters I can pull out my last semester's orientation to a lesson so we talk about that link, the assignment, what's the problem. So rather than go back and redo it each time now, I use the previous semester's posts as a guide." 
In comparison, the novice instructors found their teaching online was not that time consuming because

"I don't allow it to consume my time. I think it is tempting to sit online all the time and do that. I know these are the times I'm going to work on (my online course). I have two and a half hours of office hours, so I am online only during that period of time ... So if somebody wants to find me, they can find me online and make sure I answer all my emails [within WebCT] during that period of time."

The four instructors who reported increased workload also claimed to interact a lot with students in the discussion forum by releasing questions, providing instructions for assignments, and responding to student posts.

\section{DISCUSSION AND CONCLUSIONS}

This study found that, although almost every instructor claimed to be a facilitator in the online course, the frequency and type of participation online varied dramatically. Clearly, the instructors held different opinions about what it means to facilitate and what the responsibilities are in the facilitation of discussion in this environment. As stated earlier, some placed the responsibility on the student, claming that it was the students' responsibility to learn and that the instructor's role was to set up the course, structure the discussions, and grade the writing assignments. Others considered it their responsibility to answer students' questions, provide constant feedback, and direct learning closely in the virtual classroom, mirroring guidelines cited in much of the literature for effective teaching online [9, 13, 2, 16].

In this study, online instructors could be classified into one of three types: (1) online monitor $(<75$ instructor postings), who was visible primarily at the beginning of the course and read each message, yet rarely participated in the discussion; (2) online facilitator (125-275 instructor postings), who released questions, occasionally provided feedback to individuals in the discussion, provided guidelines for assignments, and fostered a climate of student collaboration; (3) online teacher/participant (>450 postings), who was highly visible in the discussion throughout the class, was responsive to student discussions, and interacted with students back and forth—in effect "teaching" in the virtual community.

Figure 3 indicates that instructor participation varies considerably among these three types. Whereas the online monitors were minimally present, the online teacher contributed almost 500 postings, several per day and in total almost 40 percent of the overall class postings. The online facilitators, on the other hand, seemed to have more balance among the three roles (i.e., social, managerial, and pedagogical), and interestingly the student postings in these courses were higher than those in the monitor or teacher-led courses. This finding on student participation suggests that in combination the three roles bring about higher student engagement than enacting the pedagogical role alone, even when the faculty member engages this role at a very high level. This finding also suggests that enacting multiple roles, i.e., having a balance in type of faculty participation, supports not only student engagement but results in a decreased faculty workload in the discussion area. Our research suggests that by blending roles faculty may increase efficiency online while not decreasing effectiveness. Additional research should address how online faculty roles may differ from face-to-face roles and how online teaching approaches can bring about student outcomes comparable to those found in the traditional classroom. Can the same diversity observed in face-to-face teaching styles be brought to the online environment and still reach similar student learning outcomes? 
Figure 3: Instructor and Student Postings Across Instructor Type

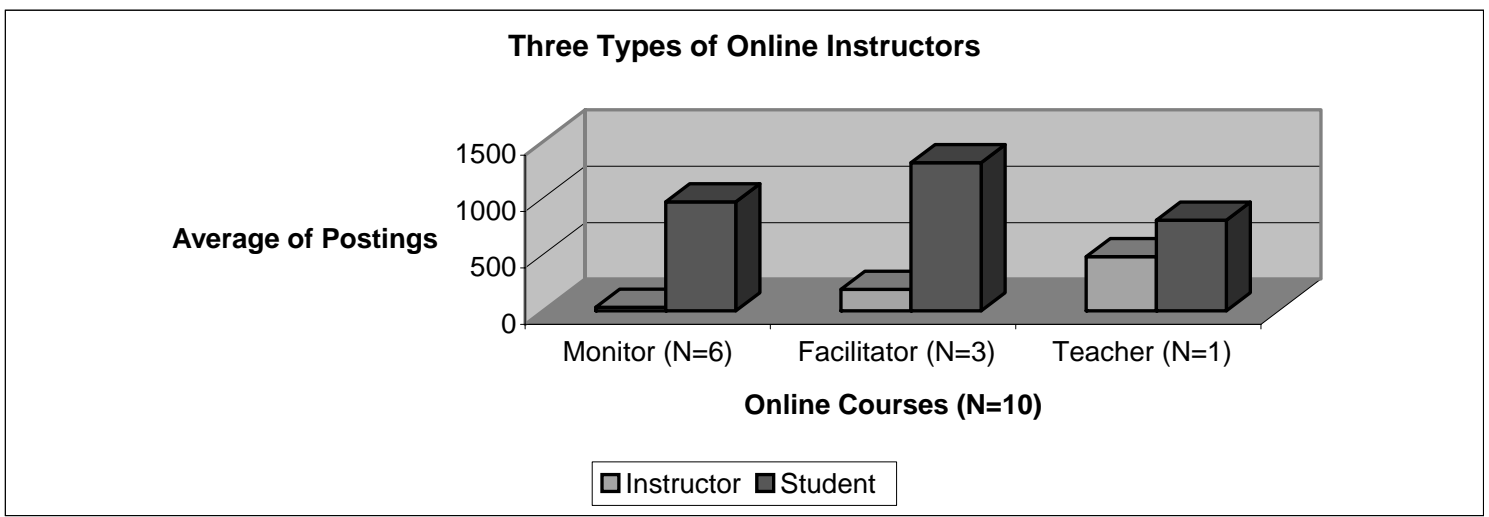

In terms of the leading role, online monitors, who were more likely to be novice instructors, primarily played a combination of managerial and social roles, whereas the online facilitator and teacher tended to be more experienced and devoted more time and attention to enacting a pedagogical role (Figure 4).

Figure 4: Instructor Posting Type Compared by Role

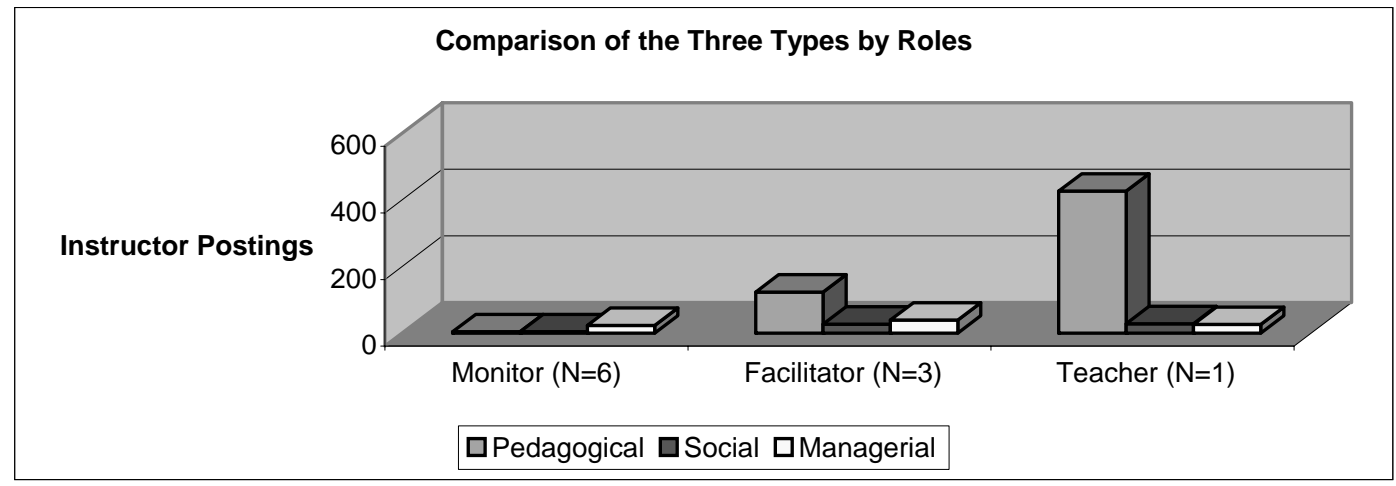

From on the categorization of discussion postings, it is also clear that the novice instructors were not providing much in the way of either information feedback or acknowledgement feedback as described by Graham et al. [25]. This finding confirmed previous research that teaching online is a learning curve [18, 19]; novice online instructors entered the new delivery medium with little knowledge of what online teaching means and the strategies that are effective in facilitating the online course.

Contradicting those studies that report a greatly increased workload for faculty in the online environment $[3,5,21,22,30]$, this study found that workload is directly related to the enacted faculty roles. A closer look at the ratio of the student-instructor postings (Figure 5) seems to confirm the relationship between these variables. Figure 5 shows that the overall ratio of faculty to student postings is approximately 1:8.5; those functioning as online facilitator or online teacher yielded an even lower ratio, evidence of their increased participation. Those who viewed their role as online monitor saw the course largely as "selfdirected study" and spent less time in directing discussions. Those who saw the course as a delivery mechanism for their teaching envisioned a teaching role as advocated in the literature, and they posted more frequently, entered more directly into discussions, and were present online. The former instructors were less concerned about the time demands of online instruction; the latter instructors were more experienced and had learned how to be more efficient in their time allocation. 
Figure 5: Ratios of Student Postings to Faculty Postings Across Instructor Type

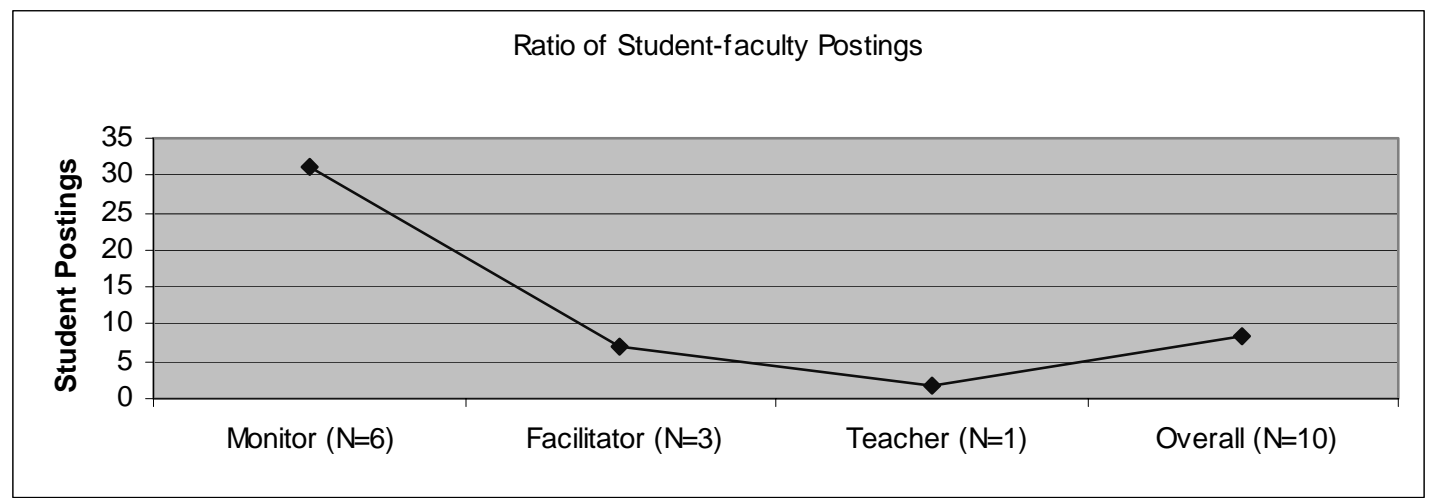

The courses included in this study were designed with multiple assessments throughout the course, thereby emphasizing in the structure of the course the faculty member's role as evaluator. All of the instructors said that grading was a time-consuming and ongoing task in these courses. In all of the interviews, faculty could describe clearly their methods of evaluating student work (e.g., grading essays or reviewing answers on quizzes). From the interviews, it was found that instructors could not speak with the same articulation about leading discussions online as they could about evaluating student work in this environment. Evidently, the skills of evaluation are more easily transferable to the online environment than the skills of discussion. Although feedback on student learning through assessment and evaluation is an important part of teaching, it is only one of the necessary ingredients for effectiveness in this environment according to multiple scholars in the field [13, 43, 15, 3]. Additionally, feedback to students through assessment and evaluation was largely a private conversation between the student and faculty in the manner of a returned paper or quiz; thus the class as a whole did not benefit from this instructor-tostudent feedback.

Because much of the literature on teaching effectiveness or best practices in the online environment describes the importance of building community online or facilitating discussions $[3,18]$, and because most of those interviewed spoke of their role as facilitator, this research raises the following questions: (1) what does facilitation mean to novice and experienced online instructors; (2) how do these different conceptions of facilitation lead to enacting various roles in the online environment; and (3) how do the various conceptions of facilitation interact with workload. Clearly, the definition and type of facilitation was not uniform across the instructors in this study.

What other influences affect the roles that faculty enact in the online classroom? The online environment per se is certainly an important factor in that novice instructors were faced with learning how to use the new technology both from a technical and instructional standpoint. Some of the novices spoke of how the courses "practically teach themselves"; consequently, they saw only a limited role for the instructor in the online environment. Clearly, the novices did not envision the multiple instructional roles carried out by the more experienced instructors. The more experienced instructors saw the technology as a delivery mechanism, not an instructional strategy.

There are several limitations to this study that we hope to address in future work. Learning about faculty behavior and roles online is only one part of the equation in teaching and learning. A central question is, what did the students do online in view of such varied faculty behavior? Did faculty engagement of their roles appear to affect student behavior and student learning? Also, did faculty enact teaching roles when giving feedback to students on assessments, or was the feedback primarily a grade? Perhaps more 
"teaching" was going on between faculty and students in the e-mail component and the evaluation component of the course than appears in the public area of these courses. To answer these questions will require gaining direct access to student papers and examinations.

Also, this study only looked at the quantity and type of faculty posting; no consideration was given to the quality of the faculty postings. Where is the diminishing return to enhancing student learning in the wide range of 5 to 480 faculty postings? Additionally, it is not known how the students evaluated the various courses and if those course evaluations correlated with instructor presence in the online environment. Access to course evaluations will give the student perspective on faculty roles in the online environment.

It would also be useful to examine courses that are designed and taught by the same faculty member. Do instructor-designed online courses require a greater engagement of the faculty role than specially designed courses? Are there upper limits and lower limits on optimal faculty engagement in relation to effectiveness? These and many other questions need to be explored to fully develop the pedagogy of teaching online.

In summary, this study reveals the variation in participation online between novice and experienced instructors and shows the discrepancies between described and enacted faculty roles. Also highlighted is the interaction among course design, the instructor's attitude toward participation, instructor activity online, and perceptions and indicators of workload. Clearly, the instructors in this study enacted various roles in the online environment, and they managed their time as an expression of these interpretations. To understand teaching online and to bring about improvements in faculty development programs, much more needs to be known about how instructors understand and enact facilitation in the online environment.

\section{REFERENCES}

1. Allen, I. E., and J. Seaman. Sizing the Opportunity: The Quality and Extent of Online Education in the United States, 2002 and 2003. The Sloan Consortium, 2003. Available online: http://www.sloanc.org/resources/sizing_opportunity.pdf.

2. Berge, Z. L. Facilitating Computer Conferencing: Recommendations from the Field. Educational Technology 35(1): 22-30, 1995.

3. Palloff, R. M., and K. Pratt. Building Learning Communities in Cyberspace: Effective Strategies for the Online Classroom, 7, 1st ed. San Francisco, CA: Jossey-Bass Publishers, 1999.

4. Allen, G. D. Online Calculus: The Course and Survey Results. Computers in the Schools 17(1-2): 17-30, 2001.

5. Collis, B., and G. G. Nijhuis. The Instructor as Manager: Time and Task. Internet and Higher Education 3(1-2): 75-97, 2000.

6. Ko, S. S., and S. Rossen. Classroom Management. In: Ko, S. S., and Rossen, S. (Eds.), Teaching Online: A Practical Guide, 211-253. Boston, MA: Houghton Mifflin, 2001.

7. Bibeau, S. Social Presence, Isolation, and Connectedness in Online Teaching and Learning: From the Literature to Real Life. Journal of Instruction Delivery Systems 15(3): 35-39, 2001.

8. Bonk, C. J., and V. P. Dennen. Frameworks for Research, Design, Benchmarks, Training, and Pedagogy in Web-based Distance Education. In: Moore, M. G. and Anderson, W. G. (Eds.), Handbook of Distance Education, 331-348. Mahwah, NJ: L. Erlbaum Associates, 2003. 
9. Bischoff, A. The Elements of Effective Online Teaching: Overcoming the Barriers to Success. In: White, K. W. and Weight, B. H. (Eds.), The Online Teaching Guide: A Handbook of Attitudes, Strategies, and Techniques for the Virtual Classroom, 57-72. Boston, MA: Allyn and Bacon, 2000.

10. Easton, S. S. Clarifying the Instructor's Role in Online Distance Learning. Communication Education 52(2): 87-105, 2003.

11. Heerema, D. L., and R. L. Rogers. Learning from the Past. Educause Quarterly 25(1): 34-38, 2002.

12. Addesso, P. Online Facilitation: Individual and Group Possibilities. In: White, K. W. and Weight, B. H. (Eds.), The Online Teaching Guide: A Handbook of Attitudes, Strategies, and Techniques for the Virtual Classroom, 112-123. Boston, MA: Allyn and Bacon, 2000.

13. Collison, G., B. Elbaum, S. Haavind, and R. Tinker. Facilitating Online Learning: Effective Strategies for Moderators. Madison, WI: Atwood Pub, 2000.

14. Hiss, A. Talking the Talk: Humor and Other Forms of Online Communication. In: White, K. W. and Weight, B. H. (Eds.), The Online Teaching Guide: A Handbook of Attitudes, Strategies, and Techniques for the Virtual Classroom, 24-36. Boston, MA: Allyn and Bacon, 2000.

15. Berge, Z. L., and L. Muilenburg. Designing Discussion Questions for Online, Adult Learning. Educational Technology 40(5): 53-56, 2000.

16. Clark, J. Simulating Collaboration and Discussion in Online Learning Environments. The Internet and Higher Education 4(2): 119-124, 2001.

17. Astleitner, H. Teaching Critical Thinking Online. Journal of Instructional Psychology 29(2): 53-76, 2002.

18. Palloff, R. M., and K. Pratt. Lessons from the Cyberspace Classroom: the Realities of Online Teaching. San Francisco, CA: Jossey-Bass, 2001.

19. Conrad, D. University Instructors' Reflections on Their First Online Teaching Experiences. Journal of Asynchronous Learning Networks 8(2): 31-44, 2004.

20. Kanuka, H., D. Collett, and C. Caswell. University Instructor Perceptions of the Use of Asynchronous Text-based Discussion in Distance Courses. American Journal of Distance Education 16(3): 151-168, 2002.

21. National Education Association. A Survey of Traditional and Distance Learning Higher Education Members, National Education Association, 2000.

Available online: http://ww.nea.org/he/abouthe/dlstudy.pdf.

22. Bradburn, E. M., and L. Zimbler. Distance Education Institution by Postsecondary Faculty and Staff: Fall 1998 (NCES 2002-155): U.S. Department of Education, Office of Educational Research and Improvement, National Center for Educational Statistics, 2002.

Available online: http://nces.ed.gov/pubsearch/pubsinfo.asp?pubid=2002155.

23. Conceicao-Runlee, S. Faculty Lived Experiences in the Online Environment, 150. University of Wisconsin-Madison, Diss., 2001.

24. Schifter, C. C. Faculty Participation in Asynchronous Learning Networks: A Case Study of Motivating and Inhibiting Factors. Journal of Asynchronous Learning Networks 4(1): 15-22, 2000.

25. Graham, C., K. Cagiltay, B.-R. Lim, J. Craner, and T. M. Duffy. Seven Principles of Effective Teaching: A Practical Lens for Evaluating Online Courses. Technology Source, March/April 2001. Available online: http://ts.mivu.org/default.asp?show=article\&id=839.

26. Bonk, C. J., J. Kirkley, N. Hara, and V. P. Dennen. Finding the Instructor in Post-secondary Online Learning: Pedagogical, Social, Managerial and Technological Locations. In: Stephenson, J. (Ed.), Teaching and Learning Online: New Pedagogies for New Technologies, 76-97. London: Kogan Page, 2001.

27. Chizmar, J. F., and D. B. Williams. What Do Faculty Want? Educause Quarterly 1: 18-24, 2001. 
28. Rockwell, S. K., J. Schauer, S. M. Fritz, and D. B. Marx. Incentives and Obstacles Influencing Higher Education Faculty and Administrators to Teach via Distance. Online Journal of Distance Learning Administration 2(3): 1999.

Available online:http://www.westga.edu/ distance/rockwell24.html.

29. Wolcott, L. L., and K. Betts. What's in It for Me: Incentives for Faculty Participation in Distance Education. Journal of Distance Education 14(2): 34-49, 1999.

30. Visser, J. V. Faculty Work in Developing and Teaching Web-Based Distance Courses: A Case Study of Time and Effort. American Journal of Distance Education 14(3): 21-32, 2000.

31. DiBiase, D. Is Distance Teaching More Work or Less Work? American Journal of Distance Education 14(3): 7-19, 2000.

32. Moore, M. G. Is Distance Teaching More or Less Work. American Journal of Distance Education 14(5): 1-5, 2000.

33. DiBiase, D. The Impact of Increasing Enrollment on Faculty Workload and Student Satisfaction over Time. Journal of Asynchronous Learning Networks 8(2): 45-60, 2004.

34. Wilson, C. Concerns of Instructors Delivering Distance Learning via the WWW. Online Journal of Distance Learning Administration 1(3): 1998.

Available online: http://www.westga.edu/ distance/wilson13.html.

35. Lazarus, B. D. Teaching Courses Online: How Much Time Does It Take? Journal of Asynchronous Learning Networks 7(3): 47-54, 2003.

36. Coffey, A., and P. Atkinson. Making Sense of Qualitative Data: Complementary Research Strategies. Thousand Oaks, CA: Sage, 1996.

37. LeCompte, M. D., and J. Priessle. Ethnography and Qualitative Design and Education Research, 2nd ed., San Diego, CA: Academic Press, 1993.

38. Charmaz, K. Grounded Theory: Objectivist and Constructivist Methods. In: Denzin, N.K. and Lincoln, Y.S. (Eds.), Handbook of Qualitative Research, 509-535. Thousand Oaks, CA: Sage, 2000.

39. Lincoln, Y. S., and E. G. Guba. Naturalistic Inquiry. Beverly Hills, CA: Sage Publications, 1985.

40. Denzin, N. K., and Y. S. Lincoln. Handbook of Qualitative Research, 2nd ed., Thousand Oaks, CA: Sage Publications, 2000.

41. Patton, M. Q. Qualitative Research and Evaluation Method, 3rd ed.. Thousand Oaks, CA: Sage Publications, 2002.

42. Creswell, J. W. Qualitative Inquiry and Research Design: Choosing among Five Traditions. Thousand Oaks, CA: Sage Publications, 1998.

43. Hacker, D. J., and D. S. Niederhauser. Promoting Deep and Durable Learning in the Online Classroom. In: Weiss, R. E., Knowlton, D. S., and Speck, B. W. (Eds.), Principles of Effective Teaching in the Online Classroom, 53-64. San Francisco, CA: Jossey-Bass, 2000.

\section{ABOUT THE AUTHORS}

Dr. Libby V. Morris is associate professor and graduate coordinator in the Institute of Higher Education at the University of Georgia. The institute is an instruction, research, and service unit of the university and offers the $\mathrm{PhD}$ and EdD in higher education. Dr. Morris holds a PhD from the University of North Carolina, Chapel Hill.

Her research interests include evaluation and assessment, instructional technology, and educational demographics. At the Institute of Higher Education she teaches courses on assessment and academic programs, and she coordinates the Faculty Development in Georgia program. She is also the principal 
investigator for a multi-year grant to investigate teaching and learning online in collaboration with the Advanced Learning Technologies unit of the Board of Regents of the University System of Georgia.

Dr. Morris has written and consulted extensively with colleges in the areas of assessment and evaluation. She has provided technical assistance and guided needs assessment and evaluation studies for numerous health professions educational programs. She is the editor of the journal Innovative Higher Education, and she is the author or co-author of several books, including, Multiculturalism in Academe, The Southern Black Belt-A National Perspective, and Georgia's Health Professions: A Decade of Change, 1985-1995.

Ms. Haixia Xu is a PhD candidate in the Institute of Higher Education at the University of Georgia. Her research interests include distance education, assessment and evaluation, and comparative higher education. She has been working with Dr. Libby V. Morris on several projects concerning online education.

Dr. Catherine Finnegan is the Associate Director for Assessment and Public Information with the Advanced Learning Technologies (ALT) unit of the Board of Regents of the University System of Georgia. ALT coordinates system-wide efforts to provide reliable and robust technology infrastructure; standardize processes; and design instructional opportunities for use by multiple campuses through the facilitation of collaborative development efforts, instructional technology planning, and evaluation.

Dr. Finnegan has responsibility for collecting, evaluating, and disseminating information for ALT's projects. She coordinates course and training evaluation and outcomes and process assessment, designing and commissioning studies that investigate the effectiveness of integration of technology in instruction and the coordination and development of accountability reporting structures.

Prior to joining ALT, Dr. Finnegan served as the Director of Institutional Research and Planning at North Georgia College and State University. Dr. Finnegan earned her doctoral degree in higher education administration from the University of Georgia. 